\title{
Effect of weed management practices on yield, weed control efficiency, weed index and economics in summer groundnut (Arachis hypogaea L.)
}

\author{
N.S. Mavarkar ${ }^{1 *}$, M.M. Gandhi ${ }^{2}$ M.S. Nandish${ }^{1}$, R. Nagaraj ${ }^{1}$ and C.J. Sridhara ${ }^{1}$
}

\begin{abstract}
A field experiment was conducted during summer 2009 under irrigation on weed management practices in summer groundnut (Arachis hypogaea L.). The experiment was conducted at the College of Agriculture and Zonal Agricultural Research Station farm, Shimoga, Karnataka, India. Recommend cultural practices recorded a higher pod yield $\left(2880 \mathrm{~kg} \mathrm{ha}^{-1}\right.$ ), which was statistically in par ( $\left.p>0.05\right)$ with preemergence application of imazethapyr at $100 \mathrm{~g} \mathrm{a.} \mathrm{i.} \mathrm{ha}^{-1}\left(2791 \mathrm{~kg} \mathrm{ha}^{-1}\right)$. Application of herbicides recorded a higher weed control efficiency compared to farmer's practice and weedy check. Among the herbicides tested, the pre-emergence application of imazethapyr (100 g a.i. ha ${ }^{-1}$ ) performed better than alachlor (2.0 kg a. i. ha ${ }^{-1}$ ), metolachlor at $1.0 \mathrm{~kg}$ a.i. $\mathrm{ha}^{-1}$ ) and pendimethalin (1.0 kg a. i. ha ${ }^{-1}$ ). Pre-emergence application of imazethapyr (100 g a. i. ha ${ }^{-1}$ ) recorded a higher net returns (Indian 53,220 ha ${ }^{-1}$ ) and a higher benefit:cost ratio (2.22) among the herbicide treatments.
\end{abstract}

Keywords: Groundnut, pod yield, pre-emergent, weed index and weed control efficiency

\section{Introduction}

Groundnut (Arachis hypogaea L.) is one of the most important oilseed crops of India. Summer groundnut crop is generally sown in January, due to low atmospheric temperature. Due to a slow growth rate up to 45 days after sowing, this crop is severely affected by weeds (Mohapatra, 2005). Mechanical control of weeds has become due to increased cost of operation and scarcity of labour (Gujjari et. al., 1995), though time consuming, expensive and tedious. Chemical control of weeds forms an excellent alternative to manual weeding. The productivity of groundnut under irrigated condition in Karnataka in India during Rabi and summer condition is not stable due to various reasons, with weed infestation serving as one of the major problems (Kori et al., 1997). Weeds not only compete with crops for moisture, nutrient, sunlight and space, but also interfere with pegging, pod development and harvesting of groundnut. Yield loss due to weed infestation varied from $17 \%$ to $84 \%$ in groundnut (Dharam et al., 1992). The present experiment was conducted to study the efficacy of pre-

\footnotetext{
1 College of Agriculture, University of Agricultural and Horticultural Sciences, Shimoga, India

2 Mahyco Seeds, Davanagere, Karnataka, India

* Corresponding author: mavarkarns@yahoo.co.in
} 
emergence and post-emergence application of herbicides and cultural (agronomic) practices in controlling weeds of summer groundnut.

\section{Materials and Methods}

A field study was conducted in red loamy sand soil during summer 2009 at the College of Agriculture and Zonal Agriculture Research Station farm, Shimoga, India. The experiment was laid out in a randomized complete block design with three replicates, and consisted of 14 treatments of which 10 treatments were herbicidal applications. Five herbicides were applied as pre-emergence (pre-em) and the rest were post-emergence (post-em). Seven herbicides were new compounds viz., aryloxyphenoxypropionics (fenoxaprop-P, fluazifop-P and quizalofop-P), diphenylethers (oxyfluorfen), imidazolinones (imazaquin and imazethapyr) and sulfonylurea (chlorimuron-ethyl) herbicide groups. These herbicides were compared with the recommended herbicides such as acetamide (alachlor, metolachlor) and dinitroaniline (pendimethalin) group herbicides. The application rate and time of application are shown in Table 1. The farmer-practice i.e. two inter-cultivations at 20, 40 days after sowing (DAS) followed by one hand weeding at 40 DAS (2 IC $+1 \mathrm{HW}$ ) and recommended cultural practice i.e. hand weeding at 20 and 40 DAS followed by two intercultivations @ 30 and 45 DAS (2 $\mathrm{HW}+\mathrm{IC}$ ) along with two controls viz. weedy check (un-weeded control) and weed-free check (weed-free throughout the crop duration) were used. These treatments were imposed to groundnut (A. hypogaea) variety TMV-2 (bunch type) in the summer season. The soil of the experimental site was an Alfisol having $210.5,50.4$ and $290 \mathrm{~kg} \mathrm{ha}^{-1}$ of $\mathrm{N}, \mathrm{P}_{2} \mathrm{O}_{5}$ and $\mathrm{K}_{2} \mathrm{O}$, respectively, with $\mathrm{pH} 6.5 \mathrm{pH}$ and $0.53 \%$ of organic carbon. The crop was sown at $30 \mathrm{~cm} \times 10 \mathrm{~cm}$ spacing and fertilized with 25:75:38 kg N: $\mathrm{P}_{2} \mathrm{O}_{5}: \mathrm{K}_{2} \mathrm{O} \mathrm{ha}^{-1}$ in the form of urea, single super phosphate and muriate of potash, respectively. The net plot size was $4.2 \mathrm{~m} \times 3.6$ $\mathrm{m}$. Net returns were calculated based on the prevailing market price during the experimental period. The weed control efficiency (WCE) was calculated on dry weight basis by adopting the Equation 1 (Mani et al., 1976) and expressed in percentage.

WCE $(\%)=\frac{\begin{array}{c}\text { Weed dry weight in } \\ \text { the }\end{array} \quad \begin{array}{c}\text { Weed dry weight } \\ \text { in the treatment } \\ \text { un-weeded control }\end{array}}{\text { Weed dry weight in the un-weeded control }} \times 100 \quad$ (Equation 1)

Similarly, the weed index (WI) was calculated on seed yield basis by using the Equation 2 (Gill and Vijayakumar, 1969) and expressed in percentage. The benefit $\operatorname{cost}(B: C)$ ratio was based on gross returns. 
Yield of the crop in weed free plot - Yield of treated plot

WI (\%) $\times 100$

(Equation 2)

Yield of weed free plot

The results were analyzed following the Fisher's method of analysis of variance (Cochran and Cox, 1965), with the level of significance tested at $p=0.05$.

\section{Results and Discussion}

\section{Nature of weed flora}

The predominant weed flora observed in the experimental field includes grass weeds such as Cynodon dactylon (L.) Pers. Dactyloctenium aegyptium (L.) P. Beauv, Dicanthium annulatum F., Digitaria marginata Link., Echinochloa colonum L., Eleusine indica (L.f.) Gaertner, Erogrostis pilosa (L.) P. Beauv. And Panicum repens L.. The broad-leaved weeds included Acanthospermum hispidum D.C., Ageratum conyzoides L., Amaranthus spinosus L., A. viridis L., Bidens pilosa L., Celosia argentea L., Cleome monophylla L., Commelina benghalensis L., Euphorbia heterophylla L., Lagascea mollis Cav., Mollugo pentaphylla L., Phyllanthus niruri L., Portulaca oleracea L., Sida acuta N. Burman) and Spilanthus acmella (L.) Murr., and sedges such as Cyperus iria L. and C. rotundus L.

\section{Effect on crop yield}

The data presented in Table 1 indicate that the pod yield of groundnut differed significantly $(p<0.05)$ due to different weed control treatments. The recommended cultural practice recorded a higher pod yield ( $\left.2880 \mathrm{~kg} \mathrm{ha}^{-1}\right)$, which was statistically similar $(p>0.05)$ with plots subjected to pre-emergence application of imazethapyr (100 g a.i. ha ${ }^{-1}$ ), alachlor (2.0 kg a.i. ha ${ }^{-1}$ ), metolachlor (1.0 kg a.i. ha ${ }^{-1}$ ), pendimethalin (1.0 kg a.i. ha-1) and oxyfluorfen (100 g a.i. ha ${ }^{-1}$ ). The lowest pod yield was recorded with farmer's practice (1700 kg ha $\left.{ }^{-1}\right)$. Among the herbicidal treatments, post-emergence application of fenoxaprop-P (75 g a.i. ha ${ }^{-1}$ ) recorded a significantly lower pod yield $\left(2227 \mathrm{~kg} \mathrm{ha}^{-1}\right)$, which was similar ( $\left.p>0.05\right)$ to that observed in quizalofop-P (50 g a.i. ha ${ }^{-1}$ ) and fluazifop-P (100 g a.i. ha ${ }^{-1}$ ). In the present study, pre-emergence application of imazethapyr (100 g a.i. ha ${ }^{-1}$ ) gave the highest pod yield among the herbicides tested owing to effective control of weeds from the early growth stages. Similar result was also recorded by Jayarama (2001).

\section{Weed index and higher weed control efficiency}

Application of herbicides recorded a lower weed dry weight and weed index (WI) (higher weed control efficiency - WCE) compared to the farmer's practice and weedy check. Among the herbicides evaluated, the pre-emergence application of 
Imazethapyr (100 g a.i. ha ${ }^{-1}$ ) performed better than alachlor (2.0 kg a.i. ha ${ }^{-1}$ ), metolachlor (1.0 kg a.i. ha $\left.{ }^{-1}\right)$ and pendimethalin (1.0 kg a.i. ha $\left.{ }^{-1}\right)$ with respect to WCE and WI. These results were supported by the observations made on dry weight of weeds recorded at harvest (Table 1 ). These herbicides are relatively broad spectrum and thus, have minimized emergence and growth of most weeds. These results confirm the earlier findings of Selvamani and Sankaran (1992) in groundnut.

Table 1. Pod yield, weed dry weight, weed control efficiency and weed index at harvest in summer groundnut as influenced by weed management practices

\begin{tabular}{|c|c|c|c|c|}
\hline Treatments & $\begin{array}{c}\text { Pod yield } \\
\left(\mathrm{kg} \mathrm{ha-}^{-}\right)\end{array}$ & $\begin{array}{c}\text { Weed dry } \\
\text { weight } \\
\left(\mathrm{kg} \mathrm{ha}^{-1}\right)\end{array}$ & $\begin{array}{c}\text { Weed } \\
\text { Control } \\
\text { Efficiency } \\
(\%)\end{array}$ & $\begin{array}{c}\text { Weed } \\
\text { Index } \\
(\%)\end{array}$ \\
\hline Alachlor (2.0 kg*), Pre-em, 1 DAS & 2702 & 136 & 87.9 & 9.0 \\
\hline Metolachlor (1.0 kg), Pre-em, 1 DAS & 2650 & 162 & 85.5 & 10.7 \\
\hline Pendimethalin (1.0 kg), Pre-em, 1 DAS & 2598 & 189 & 83.2 & 12.5 \\
\hline Oxyflourfen (100 g), Pre-em, 1 DAS & 2546 & 215 & 80.8 & 14.2 \\
\hline Imazethapyr (100 g), Pre-em, 1 DAS & 2791 & 90 & 91.9 & 6.0 \\
\hline Chlorimuron (10 g), Post-em, 15 DAS & 2420 & 279 & 75.1 & 18.5 \\
\hline Imazaquin (100 g), Post-em, 15 DAS & 2494 & 242 & 78.5 & 16.0 \\
\hline Fenoxprop-P (75 g), Post-em, 15 DAS & 2227 & 378 & 66.4 & 25.0 \\
\hline Fluazifop-P (100 g), Post-em, 15 DAS & 2331 & 325 & 71.1 & 21.5 \\
\hline Quizalofop-P (50 g), Post-em, 15 DAS & 2279 & 351 & 68.7 & 23.2 \\
\hline Farmer's practice $(1 \mathrm{HW}+2 \mathrm{IC})$ & 1700 & 646 & $47 \cdot 3$ & 42.7 \\
\hline $\begin{array}{l}\text { Recommended cultural practice } \\
\qquad(2 \mathrm{HW}+2 \mathrm{IC})\end{array}$ & 2880 & 45 & 95.9 & 3.0 \\
\hline Weedy check & 989 & 1008 & 0.0 & 66.6 \\
\hline Weed free check & 2970 & 0.00 & 100.0 & 0.0 \\
\hline $\mathrm{SE}( \pm)$ & 159.5 & 28.5 & $4 \cdot 3$ & 1.0 \\
\hline C.D. $(p=0.05)$ & 463.7 & 82.7 & 12.5 & 3.0 \\
\hline
\end{tabular}

* a.i. per ha; DAS=Days after sowing, Pre-em=Pre-emergence; Post-em=Post emergence; $\mathrm{HW}=$ Hand weeding; $\mathrm{IC}=$ Inter-cultivation; $\mathrm{SE}=\mathrm{Standard}$ error of the mean; C.D.=Critical difference.

The dry weight of weeds at harvest was significantly higher (646 kg ha-1; $\mathrm{p}<0.05$ ) in farmer's practice compared to the rest. Among the herbicide treatments, the post-emergence application of fenoxaprop-P (75 $\mathrm{g}$ a.i. ha $\left.{ }^{-1}\right)$, quizalofop-P (50 $\mathrm{g}$ a.i. $\left.\mathrm{ha}^{-1}\right)$ and fluazifop-P (100 $\mathrm{g}$ a.i. ha $\left.{ }^{-1}\right)$ recorded significantly higher weed dry weight $\left(378,351\right.$ and $325 \mathrm{~kg} \mathrm{ha}^{-1}$, respectively; $\left.\mathrm{p}<0.05\right)$ and higher WI (25\%, $23.25 \%$ and $21.50 \%$, respectively). This may be due to their ability to control only grassy weed species and ineffective on controlling broad-leaved weeds and sedges. 


\section{Economics}

Among the weed control treatments, the recommended cultural practice recorded higher net returns (Indian Rs. 53,984 ha') and lower marginal B:C ratio (11.06). Among the herbicide treatments, the pre-emergence application of imazethapyr (100 $\mathrm{g}$ a.i. ha ${ }^{-1}$ ) recorded the highest net returns (Indian Rs 53,220 ha ${ }^{1}$ ) and the higher B:C ratio (2.22) followed by alachlor (2.0 kg a.i. ha'; (Indian Rs. $49,985 \mathrm{ha}^{-1}$ and 2.02, respectively) and metolachlor (1.0 kg a.i. ha ${ }^{-1}$; (Indian Rs 45,873 ha $^{-1}$ and 2.02 respectively) compared to all other treatments (Table 2 ).

Table 2. Economics of weed management practices in summer groundnut

\begin{tabular}{lcccc}
\hline Treatments & $\begin{array}{c}\text { Cost of } \\
\text { cultivation } \\
\left(\text { Rs. ha }^{-1}\right)\end{array}$ & $\begin{array}{c}\text { Net return } \\
\left(\text { Rs. ha }{ }^{-1}\right)\end{array}$ & $\begin{array}{c}\text { Benefit: } \\
\text { cost } \\
\text { ratio }\end{array}$ & $\begin{array}{c}\text { Marginal } \\
\text { benefit:cost } \\
\text { ratio }\end{array}$ \\
\hline Alachlor (2.0 kg*), Pre-em, 1 DAS & 24,740 & 49,985 & 2.02 & 31.74 \\
Metolachlor (1.0 kg), Pre-em, 1 DAS & 24,260 & 49,033 & 2.02 & 45.41 \\
Pendimethalin (1.0 kg), Pre-em, 1 DAS & 24,610 & 47,250 & 1.91 & 32.67 \\
Oxyflourfen (100 g), Pre-em, 1 DAS & 24,140 & 46,286 & 1.91 & 48.32 \\
Imazethapyr (100 g), Pre-em, 1 DAS & 23,960 & 53,220 & 2.22 & 70.08 \\
Chlorimuron (10 g), Post-em, 15 DAS & 24,660 & 42,288 & 1.71 & 28.03 \\
Imazaquin (100 g), Post-em, 15 DAS & 23,750 & 45,243 & 1.90 & 83.14 \\
Fenoxprop-P (75 g), Post-em, 15 DAS & 24,460 & 37,164 & 1.51 & 28.26 \\
Fluazifop-P (100 g), Post-em, 15 DAS & 24,960 & 39,532 & 1.58 & 21.67 \\
Quizalofop-P (50 g), Post-em, 15 DAS & 24,960 & 38,097 & 1.52 & 20.84 \\
Farmer's practice (1 HW + 2 IC) & 24,850 & 22,212 & 0.89 & 12.27 \\
Recommended cultural practice & 25,650 & 53,984 & 2.10 & 11.06 \\
$\quad$ (2 HW + 2 IC) & 23,250 & 4,170 & 0.17 & - \\
Weedy check & 33,250 & 48,837 & 1.46 & 5.46 \\
\hline Weed free check
\end{tabular}

* a.i. per ha; DAS=Days after sowing, Pre-em=Pre-emergence; Post-em=Post emergence; HW=Hand weeding; IC=Inter-cultivation

\section{Conclusion}

All the weed management practices recorded significantly higher pod yield compared to weedy check. The results revealed that when labour is scarce and costly, pre-emergence herbicides such imazethapyr (100 g a.i. ha ${ }^{-1}$ ), alachlor (2.0 $\mathrm{kg}$ a.i. ha $\mathrm{h}^{-1}$ ) and metolachlor (1.0 kg a.i. ha $\left.{ }^{-1}\right)$ could be used as cost effective weed control techniques. 


\section{References}

Cochran, W.G. and Cox, G.M. (1965): Experimental designs. Asia Publishing House, Bombay, $2^{\text {nd }}$ Ed., pp. 106-116 and 293-294.

Dharam, S, Dagar, J.C. and Gangawar, B. (1992): Infestation of weeds and their management in oilseed crop. Agric. Rev. 13(3): 165-175.

Gill, G.S. and Vijayakumar (1969): Weed index - A new method for reporting weed control trials. Indian J. Agron. 14: 96-98.

Gujjari, A.K., Manjappa, K., Desai, B.K. and Chanrdanath, H.P. (1996): Integrated weed management in groundnut. J. Oilseeds Res. 12(1): 65-68.

Jayarama, K.A. (2001): Functional growth model in relation to weed management in groundnut (Arachis hypogaea L.). M.Sc. (Agri.) Thesis, Univ. Agric. Sci., Bangalore.

Kori, R.N., Goudareddy, B.S., Hunshal, C.S., Patil, S.L. and Nadagouda, B.T. (1997): Effect of weed control on nutrient uptake, weed weight and yield of groundnut. J. Oilseeds Res. 14(1): 51-54.

Mani, V.S., Chakraborty, T.K. and Gautam, K.C. (1976): Double edge weeds killers in peas. Indian Fmg., 26: 19-21.

Mohapatra, S. (2005): Effect of weed management in summer groundnut (Arachis hypogaea) and residual effect on succeeding rice (Oryza sativa). Indian J. Weed Sci. 37(3\&4): 277-278.

Selvamani, S. and Sankaran, S. (1992): Effect of influence on weed control in irrigated groundnut. Madras Agric. J. 79(4): 188-193. 